INTERNATIONAL HIGHER EDUCATION, Number 73 Fall 2013

Pages 18-19

\title{
The Problems with Cross-Border Quality Assurance
}

\author{
KEVIN KINSER and JASON E. LANE
}

Kevin Kinser is an associate professor and chair of the department of Educational Administration and Policy Studies at the State University of New York, Albany. E-mail: kkinser@albany.edu. Jason E. Lane is the Associate Provost for Graduate Education and Research at the State University of New York. E-mail: jason.lane@suny.edu. They codirect the Cross-Border Education Research Team.

IHE dedicates an article in each issue to a contribution from the Cross-Border Education Research Team (C-BERT), headquartered at the State University of New York at Albany. More information about C-BERT can be found at www.globalhighered.org. Follow us on Twitter at @CrossBorderHE.

With the rapid expansion of branch campuses and other forms of foreign educational outposts in both developed and developing nations, qualityassurance agencies are becoming more engaged in the challenging process of evaluating cross-border higher education. We argue the challenge is greater than simply helping individuals to make distinctions of academic quality in international contexts. In part, because there is no globally shared definition of quality, a problem of this work is only heightened as institutions and programs increasingly cross borders. 


\section{The Tale of Two Countries}

Despite ongoing discussions of creating multinational quality-assurance regimes, external quality assurance remains nationally organized. When an institution establishes a foreign outpost, it is obligated to abide by the laws of the host country (usually in addition to the laws of its homeland). In most cases that we are aware (Dubai and Hong Kong are two notable exceptions), the host country either modifies its existing quality assurance to meet the unique characteristics of cross-border higher education or forces the campus to modify its operations to meet the existing quality-assurance measures. The bottom line is that the host country and home country each have their own rules. The result is a series of idiosyncratic barriers and sometimes contradictory policies for institutions wishing to expand geographically, as well as logistical challenges for those charged with maintaining quality standards at home. Without a true transnational quality-assurance regime, nationally based policies will remain a source of conflict. Calls for stricter standards will not solve this inherent dilemma.

\section{Legitimate Differences IN QUALiTY}

As noted above, quality is notoriously difficult to define. But even assuming a shared definition of quality, there would be legitimate differences among institutions. Not all institutions have the resources of the Ivy League, and an important place exists for programs providing training that diverges from the research-based standards of many world-class institutions. With new models of education emerging from the private sector, innovative attempts to provide high- 
quality learning opportunities to students can look quite different from the traditional campus-based form. Few (if any) standards occur by which all institutions can be judged, and little agreement on how quality should be measured even for fundamental aspects common to all forms of higher education such as teaching. Given the variety of models and functions of cross-border higher education, establishing a threshold of quality for all foreign outposts is a difficult proposition.

\section{MARKeT Forces}

Cross-border higher education is often designed to meet market demand in the host country, whether that is from students seeking degrees or government officials looking for capacity development. This is for good reason as most such cross-border activities are expected to be self-supporting or help achieve the goals of the local government, providing a subsidy. However, as is clear from the prevalence of degree mills and other fraudulent purveyors of academic credentials, demand often is not based on quality. Privatization further encourages market forces to operate in the educational realm, by placing monetary value on student enrollments through the payment of tuition and fees. Regardless of market demands, however, quality-assurance agencies are intended to support the public good by ensuring legitimate, reliable, and sustainable institutions of higher education. In a conflict between the market and the public good, it takes a strong regulatory presence to win out. In most countries quality-assurance agencies are a relatively new and weak entity, and the pressures of the market often highlight their struggle to be effective. 


\section{Internal Processes at The Home Campus}

Quality assurance is not just sustained through external oversight; internal processes are needed as well. Procedures that work well when applied across the campus quad, however, may not have the same success when their target is half a world away. Educational traditions vary along with student preparation for advanced study, and principles of academic freedom and faculty governance have contradictory interpretations. Yet, a hub-and-spoke model prevails, where quality assumptions established at home are expected to be applied abroad. The challenge of cross-border quality assurance, then, is to establish as rigorous procedures abroad as exist on the home campus, but with appropriately accounting for local differences. The infrastructure to do this, however, is mostly lacking in the typically small and narrowly focused overseas locations. Internal oversight, therefore, continues to operate at considerable distance.

\section{TRUST}

Former US president Ronald Reagan was famous for using the expression "trust but verify" to indicate his stance on international treaties. The phrase has relevance for international quality assurance, as well. Most quality-assurance processes presume that the institution being evaluated can be trusted to honestly reveal details of its own performance and that peer reviewers will act with integrity in assessing the activities of an institution that could be a direct competitor of their own. But if the trust that undergirds the process is lacking, the veracity of the entire review process comes into question. In this respect, skepticism of assessments by other entities is embedded in most quality- 
assurance procedures and limits the traction that a transnational system needs to be successful. However, too much trust may also be a concern. If the home and host countries both assume the other has primary responsibility, or simply relies on internal institutional processes to maintain quality, then no one is watching the ship. Without trust in the integrity of the international higher education players and the reciprocity necessary to work across borders, international quality assurance will remain a buyer-beware world.

\section{CONCLUSION}

Poor-quality institutions exist within the cross-border higher education marketplace, as they do in public and private education sectors in all nations. However, by focusing the discourse about quality assurance in cross-border higher education on concerns about safeguarding students from being preyed upon by shady operators, larger issues that make quality assurance in the crossborder context problematic have become overshadowed. Quality assurance remains a largely nationally based phenomenon; however, cross-border institutions and programs must deal with at least two nations and, thus, two quality-assurance regimes. Such arrangements highlight the well-known problem of the lack of a global definition of quality, while also raising questions

about how market forces, legitimate differences of quality, and conceptions of trust impact quality assurance of foreign education outposts. 